\title{
Over-the-counter drug-induced lung injuries with both diffuse alveolar haemorrhage and diffuse alveolar damage
}

\author{
Takahito Nakamura, ${ }^{1}$ Takashi Watari, ${ }^{2}$ Yasuharu Tokuda ${ }^{3}$
}

${ }^{1}$ General and Respiratory

Medicine, Hoshigaoka Medical Centre, Hirakata, Japan

${ }^{2}$ Shimane University Hospital, Postgraduate Clinical Training Centre, Izumo, Japan

${ }^{3}$ Tsukuba University, General Internal Medicine, Mito, Ibaraki, Japan

\section{Correspondence to}

Professor Yasuharu Tokuda, yasuharu.tokuda@gmail.com

Accepted 3 September 2018

Check for updates

(C) BMJ Publishing Group Limited 2018. No commercial re-use. See rights and permissions. Published by BMJ.

\begin{tabular}{l}
\hline To cite: Nakamura T, \\
Watari T, Tokuda Y. BMJ Case \\
Rep Published Online First: \\
[please include Day Month \\
Year]. doi:10.1136/bcr-2018- \\
226626 \\
\hline
\end{tabular}

\section{DESCRIPTION}

A 41-year-old Japanese man with no underlying disease was admitted to our hospital with haemoptysis and dyspnoea. Two weeks prior to admission, he had caught a cold and took an over-the-counter drug (topikku GX), subsequently general fatigue and cough were worsening progressively. Hence, he presented to another hospital, owing to acute onset of dyspnoea on effort and haemoptysis, where chest X-ray was taken and revealed bilateral abnormal shadow in the middle lung fields, after that he was referred to our hospital.

On examination, his general appearance was moderately ill; blood pressure was $126 / 72 \mathrm{~mm} \mathrm{Hg}$, heart rate was 90 beats/min, oxygen saturation was $90 \%$ under ambient air, respiratory rate was $20 \mathrm{breath} / \mathrm{min}$ and body temperature was $38.2^{\circ}$. Chest auscultation revealed bilateral inspiratory mid to late crackles. Laboratory blood test showed mild elevation of liver function tests (Aspartate aminotransferase $42 \mathrm{IU} / \mathrm{L}$, Alanine aminotransferase $34 \mathrm{IU} / \mathrm{L})$, Lactate dehydrogenase 379 IU/L, C-reactive protein $28.2 \mathrm{mg} / \mathrm{L}$, the rest of the result including serological tests for infectious agents and autoimmune diseases were within normal limit.

Chest CT revealed bilateral non-segmental diffuse gland-glass opacities and reticular shadows extending from upper to lower lung fields (figure 1).

We performed bronchoscopy on admission day and bronchoalveolar lavage of the affected area revealed haemorrhagic findings with an increasing red cell count, and lung biopsies showed necrosis of alveolar lining cells with extravasation of fibrin (figure 2). We diagnosed drug-induced diffuse alveolar damage (DAD). The over-the-counter drug was discontinued and administration of corticosteroid made his

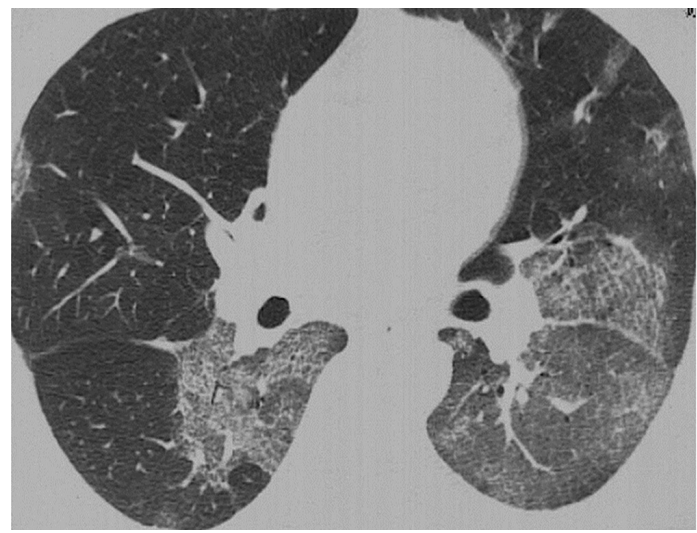

Figure 1 Chest CT on admission shows diffuse areas of ground-glass opacity.

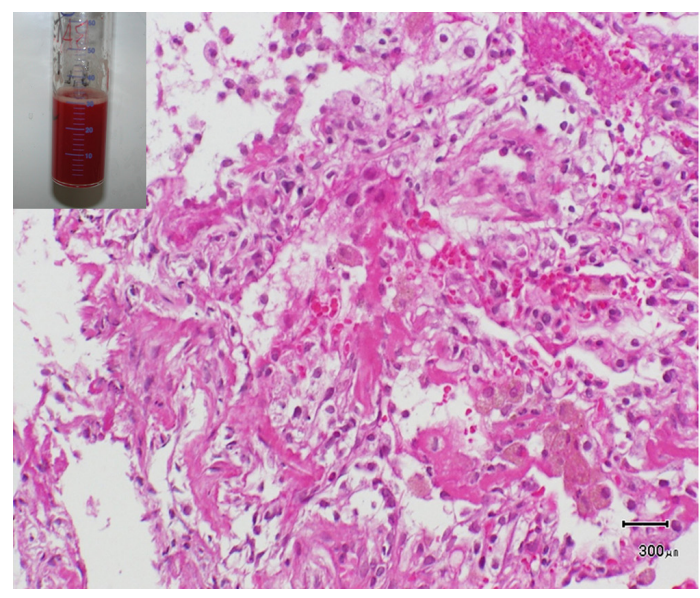

Figure 2 Lung biopsy shows prominent diffuse hyaline membranes in alveolar lumens and alveolar haemorrhage confirmed by bronchoalveolar lavage on admission.

symptoms relieved rapidly, leading to gradual tapering and then off. Finally, we performed drug lymphocyte stimulation test for the drug with exhibiting strong positive.

Though precise incidence of drug-induced lung injuries has not been accurately determined, recently the report of drug-induced lung injuries in Japan has increased since $2000 .{ }^{1} \mathrm{DAD}$ has the tendency to lower response to therapy and poor prognosis. ${ }^{2}$ It has been reported that many kinds of drugs can cause drug-induced lung injuries; however, some types of drugs such as cytotoxic agents and molecular targeting drugs may lead to trigger DAD. ${ }^{3}$ In addition, as for diffuse alveolar haemorrhage, it has been also reported that various types of medications can cause diffuse alveolar haemorrhage, such as propylthiouracil, chemotherapy agents, anticoagulants and thrombolytic agents. Generally speaking, drug-induced DAD, which is caused by cytotoxic mechanisms, may not respond to corticosteroids ${ }^{2}$; however, the patient responded to corticosteroids dramatically and chest radiograph returned to normal on fourth hospital visit. topikku GX is mainly composed of eight types of ingredients and addictives. There have been reports of lung injuries derived from ingredients of which topikku GX is composed. These ingredients are acetaminophen, chlorpheniramine, ephedrine niu-huang and dihuang. Most of the pathogenetic mechanisms by which drugs induce lung injuries are unknown. To the best of our knowledge, none has reported that 'over-the-counter drug' induced lung injuries exhibiting both diffuse alveolar haemorrhage and DAD (table 1). We should 
Table 1 Reported important drugs causing diffuse alveolar damage and alveolar haemorrhage

\begin{tabular}{ll}
\hline Chemotherapeutic agents & $\begin{array}{l}\text { Carmustine, cytarabine, docetaxel hydrate, mitomycin, } \\
\text { nitrofurantoin, gefitinib, etc }\end{array}$ \\
Antirheumatic drugs & Gold salts, etc \\
Others & $\begin{array}{l}\text { Amiodarone, cocaine, Japanese herbal medicine (sho- } \\
\text { saiko-to), etc }\end{array}$ \\
\hline
\end{tabular}

\section{Learning points}

Various types of drug-induced lung injuries including pulmonary oedema, interstitial pneumonia and eosinophilic pneumonia have been reported.

- Over-the-counter drugs may cause diffuse alveolar haemorrhage and diffuse alveolar damage.

- Clinicians should always pay attention to adverse effects of not only prescribed but over-the-counter drugs. be careful about drug-induced injuries leading to life-threatening state when respiratory symptom is rapidly worsening after taking medicine including over-the-counter drugs.

Acknowledgements The authors are extremely grateful to Dr Hiroshi Maruyama for his valuable help with the technical details of this work.

Contributors NT: cared the patient. NT, TW and YT: wrote the draft.

Funding The authors have not declared a specific grant for this research from any funding agency in the public, commercial or not-for-profit sectors.

Competing interests None declared.

Patient consent Obtained.

Provenance and peer review Not commissioned; externally peer reviewed.

\section{REFERENCES}

1 Azuma A, Kudo S. High prevalence of drug-induced pneumonia in Japan. Jpn Med Assoc J 2007;50:405-11.

2 Kubo K, Azuma A, Kanazawa M, et al. Consensus statement for the diagnosis and treatment of drug-induced lung injuries. Respir Investig 2013;51:260-77.

3 Piciucchi S, Romagnoli M, Chilosi M, et al. Prospective evaluation of drug-induced lung toxicity with high-resolution CT and transbronchial biopsy. Radiol Med 2011;116:246-63.

Copyright 2018 BMJ Publishing Group. All rights reserved. For permission to reuse any of this content visit http://group.bmj.com/group/rights-licensing/permissions.

BMJ Case Report Fellows may re-use this article for personal use and teaching without any further permission.

Become a Fellow of BMJ Case Reports today and you can:

- Submit as many cases as you like

- Enjoy fast sympathetic peer review and rapid publication of accepted articles

- Access all the published articles

- Re-use any of the published material for personal use and teaching without further permission

For information on Institutional Fellowships contact consortiasales@bmjgroup.com

Visit casereports.bmj.com for more articles like this and to become a Fellow 